\title{
The Meaning of Betrayal : L'Homme Qui A Trahi Son Nom By Tahar Ben Jelloun
}

\author{
Anistya Mustikawati Pabendan ${ }^{1}$ and Diah Kartini Lasman ${ }^{2}$ \\ ${ }^{12}$ French Department, Universitas Indonesia \\ ${ }^{1}$ anistya.mustikawati@ui.ac.id; ${ }^{2}$ deka.lasman@gmail.com
}

\begin{abstract}
Magribi Literature is a variety of literary works by writers from Magribi countries such as Algeria, Tunisia and Morocco who use French for most of their writing. In particular, Moroccan literature began to develop around the 1950s while still in the French occupation. Post-colonialism and a description of everyday life became the main themes used by Magribi writers, including Tahar Ben Jelloun. He is a Moroccan writer who uses French in most of his works. His writings are dominated by post-colonialism, love, friendship and betrayal themes which give a general picture of daily life, one of the works is Amours sorcières book which contains a collection of short stories. This article discusses the meaning of betrayal contained in one of these short stories, L 'Homme Qui A Trahi Son Nom. This research is a qualitative study using a structural approach that includes narratology theory by R. Barthes. The finding of this article is the betrayal contained in the short story is the main character who has doubts about himself so that it raises the attitude of the main character's betrayal to himself with an effort to change his name.
\end{abstract}

Keywords: post-colonialism, narratology, betrayal, identity

\section{INTRODUCTION}

The distinctive feature of Maghribi literature lies in the influence of history and culture of France which once occupied the Maghribi countries with the theme of criticism of colonization and the merging of two cultures to be the most dominant emerging[1]. Moroccan literature developed in the 1950s when Morocco was still under French occupation so that post-colonialism remained one of the major themes in the work of Moroccan writers. Many works by Moroccan writers about life in Morocco after colonialism, issues regarding identity, and problems that occur in everyday society such as patriarchy, restrictions on women's rights, and others. Tahar Ben Jelloun is a Moroccan-French poet, novelist, and essayist who is famous for his various works that use French even though his native language is Arabic. One of his famous works is Amours sorcières, a book that contains a collection of short stories and is one of the works of Tahar Ben Jelloun, published in 2003. The three major themes namely love, friendship and betrayal which provide a general description of life that is happen everyday [2]. With this big theme Ben Jelloun shows the perspective and mindset experienced by someone with a problem from one of the related themes. Amours Sorcières also contains stories inspired by authentic facts about life in Moroccoand the suffering of betrayal.

No previous studies have yet been found that have specifically addressed the short storyL'homme qui a trahi son nom. However, studies can be found on the book Amours Sorcières, a collection of short stories which include L'homme qui a trahi son nom and 
research on one of Tahar Ben Jelloun's works. One of them is Kenneth J. Fleurant in his article "Reviewed Work (s): Amours Sorcières by Tahar Ben Jelloun (2005)" which explains that in Amours Sorcières there are stories inspired by authentic facts that occur in the daily lives of people in Morocco[3].This is the ambivalence of Moroccan society so that the work is seen through the perspective of the author and is an attraction for modern readers who have an interest in literary works with different story plots. In contrast to Fleurant, the next study is a dissertation by Oom Rohmah Syamsudin from the Universitas Indonesia, namely UnsurUnsur Budaya Sebagai Dasar Konflik Dalam Novel "Les Yeux Baissés” Karya Tahar Ben Jellounin 1995 [4]. The dissertation uses a structural approach in the form of flow and distribution by dividing the unit content of the story using micro sequences in the analysis. In the research discussed about the factors that caused the emergence of conflict between immigrant families in the story with the French community in terms of language, education, religiosity, employment, and technology used.

In the two studies that have explained can be seen that the study of the short story L'homme qui a trahi son nom has not been done so that research will be conducted on the meaning of betrayal in the short story. This article will analyze the meaning of betrayal in the short story explicitly and implicitly. In Amours Sorcières, Ben Jelloun describes how the state of love, friendship, and betrayal greatly affects a person in his life as in one of his short stories, L'homme qui a trahi son nomtakes one of the big themes, betrayal. This short story tells the main character named Ahmed Lemzoudi from a remote village who wants to change his name because he wants to leave the village of his birth and start a new, better life. The story tells of betrayal as a way by the character Ahmed Lemzoudi to leave his old life and start a better life in the city.

\section{METHOD}

This studyuse a descriptive qualitative method with a structural approach that includes narratology theory by Roland Barthes [5]. Analysis is done through plot and channeling to identify the meaning of betrayal contained in the short story.Research is done through events in the story. This research also uses the theory of focalisation from G. Genette to see the use of the all-knowing third-person perspective in the narrative and the first-person perspective in the narrator's character's speech to see the meaning of betrayal contained in the short story [6].

\section{RESULT AND DISCUSSION}

\subsection{Text Narative Structure: Ahmed's Attempt to Leave His Origin Village}

Plot is a story framework that contains the sequence of events contained in a fictional text. The sequence of events there is a channel that discusses the arrangement of the sequence of events that make up the story. In determining distribution, it is used to identify the syntagmatic elements of a work. The syntagmatic and paradigmatic relationship is a relationship that is contained in a work[5]. In the syntagmatic aspect there is a linear relationship which is divided into two, namely the main function and catalyst. The main function acts as the core of the story consisting of events that make up the logic of the story, while the catalyst only completes the main function. To find the main function, sequences are needed to determine the Sequence of Story Contents so that the structure of the story can be determined.

L'homme qui a trahi son nom is a short story that tells the story of a young man named Ahmed Lemzoudi who came from a remote village, Mzouda. Ahmedwho felt bored and did not want to live forever in Mzouda decided to change his name because he wanted to leave the 
village of his birth and start a better life. In the process of changing the name, Ahmed's character met Le Fonctionnaire or the Civil Registry Officers who mocked and rejected Ahmed'sattempt to change his name, and Maître de l'école or the Principal who provide realization that he did not need to change his name to be personal and get a better future.

As seen from the structure of the text,L'homme qui a trahi son nomconsists of the title andimmediately followed by the first paragraph. In the title of the short story there is a verb trahir which means Cesser d'être fidèle à quelqu'un, à un groupe, un parti, une cause, les abandonner (Larousse.fr) or stop being loyal to someone, a group, a part, a purpose, to leave them. This short story has a linear flow with several flashback events to explain why the main character decides to change his name and leave the village of his birth.

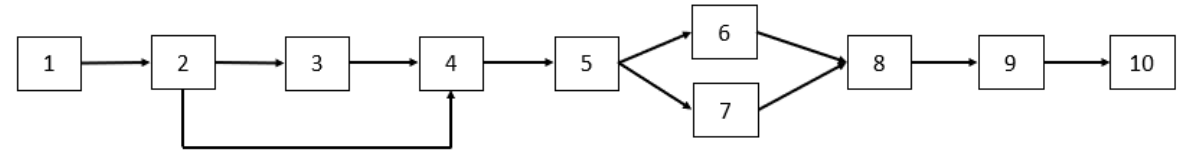

1. Description of the main character as a man who goes to the city

2. Introduction of Ahmed Lemzoudi as the main character and place of residence

3. Ahmed's desire to leave his village

4. Ahmed's decision to change his name

5. The search for a new name by Ahmed

6. Le Fonctionnaire's rejection of Ahmed's desire to change his name

7. The meeting of the Ahmed figure with the maitre d'école

8. Awareness of Ahmed's figures on his decision through the focalisation of the Principal

9. Acceptance and awareness of Ahmed's character that comes from Mzouda will always bea part of his real identity

10. The depiction of the life of Ahmed's character after leaving his village and not changing his name

Through the sequences, the fourth main function becomes the core of the story because it shows the decision of Ahmed's character to leave his village to live a better life. This indicates an identity crisis that was experienced by Ahmed's character so he felt that his life would not be better if he remained in Mzouda. Ahmed character's process of changing his name implicitly gives Ahmed a new perspective that changing his name will not change living conditions directly. However, it can be said by name, Ahmed sees this as a hope for a better life.

The causal events in the short story show the development of Ahmed's character as the main character in his efforts to change his last name or surname. It can be seen as betrayal committed by Ahmed's character is an attempt he made to break away from the old identity as part of his tribe as a form of disappointment towards himself who felt that he should not have been born from the city. The decision showed that Ahmed's desire for a better life could be realized by making himself a knowledgeable person so that he did not change his name. However, living outside the village demonstrates that Ahmed's efforts to realize this desire must leave his native village. The contrast shows that Ahmed's desire for a better life is done by building a place for himself that is neither in his village nor in the city so that it can be seen that both backgrounds become supporters of Ahmed's character to commit treason, namely his native village.

L'homme qui a trahi son nom has a big theme namely identity and betrayal committed by the main character, Ahmed which supported by events that show identity problemsthrough 
attempts by Ahmed's character to change his name by looking at various names that appear in newspapers as references and replace it many times. Identity and betrayal were also demonstrated through a change of setting in the form of Ahmed's character who wanted to leave his village, Mzouda to go to Fès, a large city in Morocco. The setting in the text shows how Ahmed's character betrayed his original identity through the transition of the spatial setting from village to city, thus showing how Ahmed's character wanted to leave the image of the poor village by going to an urban and modern city.

\subsection{Crisis Identity of Ahmed}

In the attempt of Ahmed's character to leave his native village, it related with his identity crisis. According to Stuart Hallidentity is a basic element in every individual that distinguishes it from other individuals. Identity can be divided into two, Identity as being which refers to identity that has existed since birth such as race, ethnicity, others and Identity as becoming, that is, an identity that can be changed. Identity is also something that is imaginary or imagined about wholeness. It also argues that an identity arises due to a feeling of indecision which is then filled by external forces from each individual so that identity can change according to the influence received by each individual. Identity itself is an embodiment of imagination which is seen by certain parties who are interconnected within it [7].

In line with Stuart Hall's concept of identity, in L'homme qui a trahi son nom, there is a doubt in Ahmed's character about self-identity. It started from the saturation of Ahmed's character with his original identity and current situation. With his village situation and original identity, Ahmed's character feels that he does not want to continue to live in his current condition because he feels that his life has no meaningful purpose when settling in his village. With this situation comes the saturation of identity in Ahmed's character so he feels that he must develop an identity for the formation of a new identity. This isproven by the followingquotes:

"Comment quitter ce lieu natalmaudit, comment ne plus appartenir à cette tribu qui n'a fabriquéque des immigrés et des bergers ?[...],[...] Les animaux viventdans le même espace que les humains. On s'habitue aux odeurs. Ce n'est pas très méchant.Ahmed ne s'était jamais habitué à dormir à côté des vaches. [...]j'ai vaincu la maladie et je quitterai Mzouda. [...]Je partirai à Fès, la ville des villes, la ville des livres, du savoir etde la bonne cuisine. »

"How to leave this damned place of birth? How is it no longer part of this tribe which only produces immigrants and beggars? [...], [...] Animals live in the same place as humans. We are used to the smell. That's not too bad. Ahmed never used to sleep next to the cows. [...] I have defeated the disease and I will leave Mzouda. [...] I will go to Fès. Cities of all cities, cities of books, of knowledge and delicious food. "

Through this quote there is a feeling of loss of purpose in life which means emerged from the character Ahmed with his living conditions. The quote indicates an inner conflict in Ahmed's character in the form of losing his life's purpose if he stays in his village which triggers an identity crisis. There was an attempt by Ahmed's character to betray his origins through the setting of the story by leaving his village to go to the city. The betrayal creates a feeling of guilt that continues to emerge as Ahmed tries to change his name. This shows that the Ahmed has betrayed himself because by changing the name, he has abandoned his original identity which resulted in losing his identity so he decided not to change his name.InL'homme qui a trahi son nom, Ahmed's crisis identity shows that there is something in Ahmed'spoint of view is missing or not enough. This shows a strong rejection and disagreement with his original identity so he wants to change his identity by committing treason and looking for an 
educated environment as a representation of the new identity he wants so that the decision arises to leave his native village of Mzouda and change his name.

In Ahmed's attempt to form a new identity, it can be divided into two, explicit and implicit. Efforts made by Ahmedexplicitly by changing the name show the results of an identity crisis that occurred in him so that the assumption arises that changing the name is the same as getting a better life with a clearer purpose in life because he can become a free individual who is not bound by his origin. He made the effort with the assumption that he would instantly have an identity and a new life just enough to change the name. Meanwhile, Ahmed's character implicitly tries to commit treason against himself so that the identity crisis he experiences worsens to the peak through the realization that the change that must be made is to develop oneself. Then he tried by developing his identity through culture and knowledge. With both of these efforts shows the character wants to form himself to be more cultured and educated and develop his old identity. The efforts of Ahmed's character explicitly by the character can be seen through the following quote:

«Moi aussi je suis devenu curieux de connaîtrecette ville. Je parle un peu l'arabe. Je connais des sourates duCoran. Avec ça, je peux me débrouiller. [...]Ahmedeut d'abord l'idée de changer de nom. Avant de se présenter aubureau de l'état civil, il s'installa dans un café de la place JamaaEl-Fna, demanda un journal et se mit à la recherche d'un nom.»

"Me too, I became curious about this city. I speak a little Arabic. I know the suras of the Qur'an. With that, I can manage it. [...]Ahmed initially had the idea to change his name. Before introducing himself to the civil registry office, he went to a cafe in the Jamaa El-Fna square, asking for a newspaper and looking for a name. "

The quote shows the beginning of an identity crisis in Ahmed'scaused by his obsession with the city which indicates Ahmed's efforts to replace the name with the intention to get a good life in the city. Meanwhile the covert efforts undertaken by Ahmed's character are showed in the following quote:

"[...]Quelques mois plus tard, il construisit une petite hutte endehors du village sur une colline d'où on pouvait voir d'autresmontagnes. Il aménagea cet espace, emprunta des livres d'histoireà son maître d'école et se mit à lire. Il devint l'intellectuel duvillage. On l'appela Si El Alem, Monsieur le Savant. »

"[...] A few months later, he built a small hut outside the village on a hill that could be seen by other mountains. He developed this place, borrowed history books from the Principal and read them. He became a village intellectual. We call him Si El Alem, Mr. Scientist. "

The quote shows the awareness in the character Ahmed about the betrayal he had committed against himself and shows that the identity crisis caused Ahmed to betray himself in an effort to find his identity. Through this quote there is an effort that was directly or consciously carried out by the character Ahmed in forming a new identity through a change in name. The strategy undertaken by Ahmed's character indirectly by developing himself through knowledge so that it enriches culture and knowledge makes Ahmed's character have more knowledge than the people in his city. The result of this indirect effort was the recognition from the people around him so that he earned the nickname Monsieur Le Savant. This shows that the identity crisis has become a motivation for Ahmed's character to commit betrayal so that from this attitude comes awareness in the form of a new perspective on the way Ahmed's character sees his life and life goals. 


\subsection{Contrast between Village and City: Ahmed's Treachery Motivation}

As mentioned in the previous discussion, the decision of Ahmed's character to change his name was due to his desire to leave his native village, Mzouda to live a new life in the city of Fès so that there was contrast in support of Ahmed's character's decision. In literary works there are perspectives in a story that function to provide certain meanings implicit in a work so that the message can be understood by the reader [16]. The perspectives is focalisation zéro, the narrator has an all-knowing nature.L'homme qui a trahi son nom has a focalisastionzéro that can be seen with a narrator who has an all-knowing third-person perspective. This focalisation shows how the contrast between the village and the city caused Ahmed's character to commit treason. In the story, the two settings in which the domain of the story is Mzouda and Fès. Both of these backgrounds are exterior space backgrounds that always appear in stories that show the desire of Ahmed's character to leave his home village. With these two backgrounds, the contrast between village and city shows Ahmed's efforts to change his life for the better. By going to the city he assumed that his life would be better there and leaving his village was the only way to get a better life.Mzouda as the origin villageof Ahmed is described as a poor village. It was this alarming condition that caused Ahmed's character to become disgusted and decided to leave Mzouda. In addition, the stigma and a description of the condition of the village of Mzouda in the text shows Ahmed's decision to leave his village is a result of this depiction. The discussion isshown in the followingquote;

"Quand il arriva en ville, il décida de changer de nom. Le sienn'était pas moche, mais il trahissait ses origines rurales.[...] Ahmed, né et élevé à Mzouda, levillage le plus pauvre de toute la région de Marrakech. »

"When he arrived in the city, he decided to change the name. His name is not bad, but he betrays the origin of his village. [...] Ahmed born and raised in Mzouda, the poorest village in all of Morocco. "

This shows that the character Ahmed did not intend to betray his village but he consciously wanted to leave his village so that it implies that the character Ahmed committed treason against himself because he felt that his original identity was a failure.Fès, is represented as an advanced place with a civilized society and many of them are intellectuals, have a very good life, and life in the city will be better than in the village. This also led Ahmed to leave his village so that he could get a better life in the city. Fès is a city that is the main objective of Ahmed's character who wants to leave the village of Mzouda. The city is also one of the main factors of Ahmed's character to leave the village because he always compares those two places. However, through the city of Fès shows the awareness of the character Ahmed to return to his origins and decides to change his mindset into someone with knowledge.

The contrast between the two settings shows that there was a stigmatization of the two settings that led Ahmed to decide to leave his home village. Even though he wanted to leave Mzouda, Ahmed's character still cared about his village so that by leaving his village, he unconsciously betrayed himself by trying to leave his village. This is also shown by even though Ahmed's character decided not to change his name, he still left his village and built a place for himself. 


\section{CONCLUSION}

Based on the explanation before, it can be concluded that the meaning of betrayal committed by Ahmed's character is an attempt that he is trying to do which is caused by his poor life conditions. This shows that his lack of knowledge has caused a simple solution to become the main reason for Ahmed's character to change his name. Through those efforts Ahmed's character realized about the betrayal he committed so that the meaning of betrayal that was committed by Ahmed's character was not by his name but by betraying himself. By betraying himself, Ahmed's character left the real identity he had by leaving his home village. Through the previous explanation it can be found that betrayal is the result of an identity crisis experienced by Ahmed's character so that an attempt to change his name and leave his home village. The effort then got a reaction from the surrounding environment in the form of rejectionand self-acceptance. This shows that the reaction of others has a role in making Ahmed's character aware not to change his real identity but to develop his identity by setting goals through science.

\section{REFERENCE}

[1]. N. Redouane, "La Littérature maghrébine d'expression française au carrefourdescultures et des langues." The French Review. 81-90. 1998. https://www.jstor.org/stable/399097

[2]. T. B. Jelloun and D. Simon, "A Brief Conversation with Tahar Ben Jelloun, "World Literature Today", vol. 83, (2), pp. 20-20, 2009.

[3]. K. J. Fleurant, "Reviewed Work(s): Amours Sorcières by Tahar Ben Jelloun." French Review. 2005. Article https://www.jstor.org/stable/25479950?seq=1\#page scan tab contents

[4]. O. R. Syamsudin, "Unsur-unsur Budaya Sebagai Dasar Konflik Dalam Novel "Les Yeux Baissés" Karya Tahar Ben Jelloun”. 1995. Doctoral Dissertation, Postgraduate Program Universitas Indonesia. Depok: Universitas Indonesia.

[5]. R. Barthes, "An Introduction to the Stuctural Analysis of Narrative," New Literary History: A Journal of Theory and Interpretation, vol. 6, (2), pp. 237, 1975. https://www.persee.fr/docAsPDF/comm 0588-8018 1966 num 8 1 1113.pdf

[6]. G. Genette, "Narrative Discourse: An Essay in Method."New York: Cornell University Press. 1980.

[7]. S. Hall and F. Ghazoul, "Cultural identity and diaspora," Alif: Journal of Comparative Poetics, (32), pp. 257, 2012.

[8]. H. Abdel-Jaouad, "World Literature Today". 73(4). 799-800. 1999. doi:10.2307/40155249

[9]. M. Bal, "The Point of Narratology," Poetics Today, vol. 11, (4), pp. 727-753, 1990.

[10]. J. Erickson, "Tahar Ben Jelloun's Sandchild: Voiceless narratives, placeless place. In Islam and Postcolonial Narrative." In Islam and Postcolonial Narrative. 66-95. Cambridge: Cambridge University Press. Article.1998.

[11]. C. Flaugh, "Operating Narrative: Words on Gender and Disability in Two Novels by Tahar Ben Jelloun."Forum for Modern Language Studies411-426. 2009. Available OxfordUniversityPress. Article. https://academic.oup.com/fmls/article-abstract/45/4/411/630676?redirectedFrom=fulltext

[12]. M. Klarer,“An Introduction to Literary Studies, Second edition”.London:Routledge. 2004.

[13]. Larousse. (n.d.). Larousse: Dictionnaires de français. https://www.larousse.fr/dictionnaires/francais/mole/52068

[14]. L. Ouzgane, "The Rape Continuum Masculinities in the Works of Nawal El Saadawi \& Tahar Ben Jelloun." Men in African Film and Fiction. Boydell \& Brewer. 68-80. 2011.

[15]. N. Redouane, "Reviewed Work(s): Tahar Ben Jelloun by Bernard Aresu". The FrenchReview. pp. 975-976. 2000. JSTOR, www.jstor.org/stable/398319.

[16]. T. Spencer, "Wellek, R., and Warren, A., Theory of Literature (Book Review)," The Modern Language Review, vol. 44, pp. 555, 1949. 